\title{
A new detection method for a newly revealed mechanism of pyrethroid resistance development in Varroa destructor
}

\author{
Aneta Strachecka ${ }^{1} \cdot$ Grzegorz Borsuk $^{1} \cdot$ Krzysztof Olszewski $^{1} \cdot$ Jerzy Paleolog $^{1}$
}

Received: 21 April 2015 / Accepted: 16 July 2015 /Published online: 26 July 2015

(C) The Author(s) 2015. This article is published with open access at Springerlink.com

\begin{abstract}
The Varroa destructor mite has recently displayed an ever increasing resistance to new drugs, contributing to CCD proliferation. This work was aimed at determining new viable methods for identifying the pyrethroid resistance of $V$. destructor and DNA methylation in resistant and sensitive mites. DNA was extracted from Varroa mites. Nucleotide changes in the DNA of pyrethroid-resistant, pyrethroid-sensitive, and control mites were identified with polymerase chain reaction single-strand conformation polymorphism (PCRSSCP) in the case of five mitochondrial gene fragments. More bands were observed in the drug-resistant mites than in the other two groups. Sequencing confirmed these observations. Decreased global DNA methylation levels were observed in the pyrethroid-resistant mites. There exists a previously undescribed mechanism of pyrethroid resistance development in Varroa mites. The PCR-SSCP methods can be considered and further developed as useful tools for detecting V. destructor resistance.
\end{abstract}

Keywords Varroa destructor · PCR-SSCP · Acaricides · Mitochondrial cytochrome oxidase I (COI) · Drug resistance

\section{Introduction}

Varroa destructor parasite (Fig. 1) is the crucial, worldwide problem of apiculture. It is believed to be one of the main

Aneta Strachecka

aneta.strachecka@up.lublin.pl

1 Department of Biological Basis of Animal Production, Faculty of Biology and Animal Breeding, University of Life Sciences in Lublin, Akademicka 13, 20-950 Lublin, Poland reasons for honeybee colony depopulation (Rosenkranz et al. 2010). The parasites not only weaken and damage their hosts but also transfer viruses that lead to morphological malformations and suppress host vigor, life span, flight abilities, and forager orientation (Schneider and Drescher 1987; Koch and Ritter 1991; Romero-Vera and Otero-Colina 2002; Garedew et al. 2004; Kralj and Fuchs 2006; Maggi et al. 2009; Borsuk et al. 2012). Therefore, many acaricides are in use to control the infestation of honeybees by $V$. destructor. Despite high initial acaricide performance, the adaptive potential of $V$. destructor eventually leads to the appearance of the first acaricide-resistant individuals that are capable of reproduction. It may occur even after a few years from the beginning of treatment (Mathieu and Faucon 2000; Maggi et al. 2010, 2012). Watkins (1997) found that the higher the number of Varroa generations raised under tau-fluvalinate influence, the greater percentage of the Varroa population becomes more resistant to this synthetic pyrethroid used around the world to control honeybee infestation by Varroa parasites.

The resistance within the parasite populations has a multifactorial character. First, it is associated with increased taufluvalinate detoxification abilities mediated by cytochrome P-450 monooxygenases in some parasites. Martin (2004) described the Varroa cuticle resistance as the second resistance mechanism. Our former studies confirmed high activities of proteases on cuticles of the tau-fluvalinate-resistant Varroa mites in comparison to the tau-fluvalinate-sensitive ones (Strachecka et al. 2013). Wang et al. (2002) and Liu et al. (2006) described the third resistance mechanism: Taufluvalinate causes point mutations in mitochondrial DNA (mtDNA) and thus blocks sodium channels, which increases Varroa tolerance of this pyrethroid. Yukioka et al. (1998) and Van Leeuwen et al. (2008) also discovered that Varroa resistance to this acaricide is associated with mutations of mitochondrial genes. Such mutations result in an exchange of 


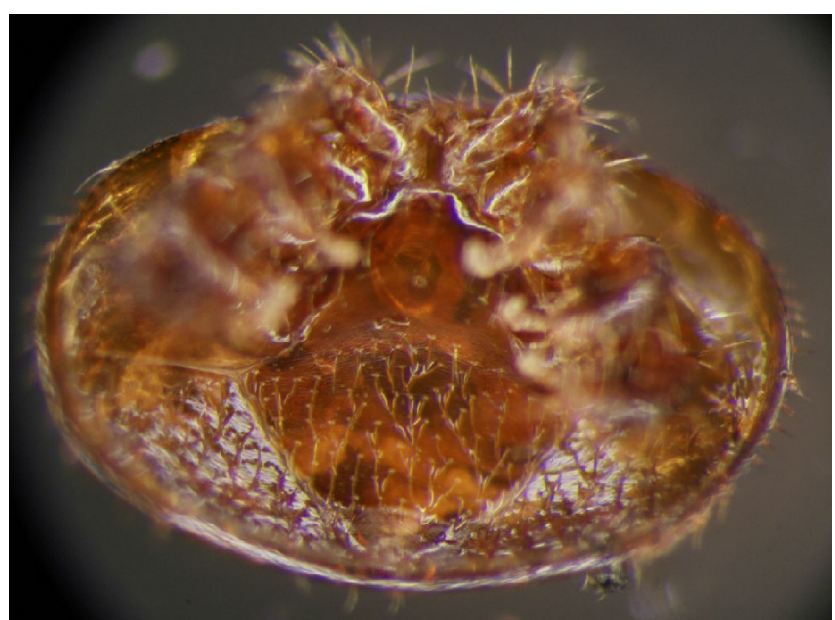

Fig. 1 Venteral view of a Varroa destructor mite

amino acids (e.g., leucine-phenylalanine) which leads to a change in the folding of proteins connected with the functioning of the sodium channel (Miyazaki et al. 1996; Williamson et al. 1996; Dong 1997; Guerrero et al. 1997; Lee et al. 1999; Park et al. 1997; Wang et al. 2002, 2003). These mtDNA mutations easily spread in the Varroa population because of the kin reproduction strategy of the mites (brothers mate with their sisters; Cornuet et al. 2006).

Mite resistance to acaricides, including tau-fluvalinate resistance, was mainly determined with the method of Milani (1995). It is difficult, however, to compare tau-fluvalinate toxicity evaluated by the Milani and the other methods (Hillesheim et al. 1996; Johnson et al. 2010) since, in these methods, the mortality and resistance of mites were assessed by applying different mediums, humidities, and temperatures.

Taking into account all the findings on $V$. destructor resistance against acaricide treatment, we believe that there is an urgent need (1) to develop new methods of resistance detection (including potential resistance) based on the assessment of parasite mtDNA mutation changes and (2) to expand the study of Varroa resistance mechanisms against acaricides, taking into consideration epigenetic mechanisms, since mtDNA mutations do not fully explain the parasite response/plasticity during acaricide treatment. Ultimately, the fast but variable and environment-dependent development of Varroa pyrethroid resistance can find a new explanation (Holliday and Grigg 1993; Xia et al. 2012; Flores et al. 2013). The aim of this study was (1) to develop a new method for detecting pyrethroid resistance of $V$. destructor based on polymerase chain reaction single-strand conformation polymorphism (PCR-SSCP) involving five mitochondrial genes. PCRSSCP is a simple and effective technique detecting changes in the nucleotide sequence of PCR products (2) to reveal the existence of a yet undescribed mechanism of $V$. destructor pyrethroid resistance connected with nuclear DNA methylation.

\section{Material and method}

One hundred $V$. destructor females were sampled from drone brood combs acquired from eastern Poland apiaries at which acaricides containing tau-fluvalinate $(150 \mathrm{mg}$ tau-fluvalinate per colony) had been applied. The females were divided into two unequal parts containing 75 and 25 of them, respectively. In the first part, the 75 females were divided into taufluvalinate-sensitive and tau-fluvalinate-resistant using test media soaked with tau-fluvalinate according to the Milani (1995) method. In the second part, 25 females were tested on pure, media that were not soaked with tau-fluvalinate, thus representing the control. Subsequently, the mites (samples) belonging to the resistant, sensitive, and control parasite groups were marked with special codes (blind samples) and refrigerated in germ-free bags at $-24{ }^{\circ} \mathrm{C}$. After defrosting, mite DNA was extracted using the DNeasy Blood \& Tissue Kit (Qiagen) according to the producer's procedure. Extracted DNA samples were stored at $-25^{\circ} \mathrm{C}$. DNA quantification was performed spectrophotometrically by measuring the absorbance at 230, 260, and $280 \mathrm{~nm}$ with a BioPhotometer (Eppendorf). The DNA samples were used both for the PCR and the global DNA methylation analyses.

\section{The polymerase chain reaction}

Five fragments from the following mitochondrial genes: cytochrome oxidase I, II, and III, ATP synthase 6, and cytochrome b (COI 320 bp, COI 929 bp, COII-ATP6 775 bp, ATP6-COIII 818 bp, and CytB 958 bp) were amplified in the PCR using the Qiagen Taq PCR Core Kit. The PCR primers (Table 1) were developed from the sequence of the complete mtDNA genome of $V$. destructor (GenBank Accession No. AJ493124.1; Evans and Lopez 2002; Navajas et al. 2002). The reaction mixture for a single sample contained $6 \mu \mathrm{l}$ DNA, $3.5 \mu \mathrm{l} 10 \times$ PCR buffer, $7 \mu \mathrm{l}$ Q buffer, $5.33 \mu \mathrm{lggl}_{2}$, $0.58 \mu \mathrm{l}$ of each dNTP, $0.33 \mu$ primers 1 and 2 , and $1 \mathrm{U}$ polymerase. The eventual volume of the sample was $30 \mu \mathrm{l}$. The amplification of the PCR products was carried out onboard Labcycler SensoQuest Biomedical Electronics (Syngen) thermocycler in accordance with the following thermal-temporal profile: preliminary denaturation at $94{ }^{\circ} \mathrm{C}$ for $3 \mathrm{~min}$; subsequently, a program of 36 repetitive cycles was employed - denaturation at $94^{\circ} \mathrm{C}$ for $1 \mathrm{~min}$, attachment of the primers at $45^{\circ} \mathrm{C}$ for $1 \mathrm{~min}$, and annealing of the primers at $72{ }^{\circ} \mathrm{C}$ for $1 \mathrm{~min}$. The final annealing of the primers was conducted at $72{ }^{\circ} \mathrm{C}$ for $10 \mathrm{~min}$. The PCR products were divided into two sets: 1 for SSCP and 2 for the sequencer.

Set 1: Ten microliters of the PCR product were supplemented with $10 \mu \mathrm{l} 2 \times$ loading dye and denaturized at $95{ }^{\circ} \mathrm{C}$ for $5 \mathrm{~min}$. The samples were separated on $8 \%$ polyacrylamide gels in the DCode ${ }^{\mathrm{TM}}$ Universal Mutation Detection System (Bio-Rad) in the following conditions: $20 \mathrm{~W}, 340 \mathrm{~V}$, and 
Table 1 Amplified DNA fragments for the detection of taufluvalinate-sensitive and tau-fluvalinate-resistant V. destructor

\begin{tabular}{|c|c|c|c|c|}
\hline Gene & Primer name & Primer sequence $\left(5^{\prime}-3^{\prime}\right)$ & $\begin{array}{l}\text { Fragment } \\
\text { size (bp) }\end{array}$ & Literature \\
\hline $\mathrm{COI}$ & $\begin{array}{l}\text { V51 } \\
\text { V1400 }\end{array}$ & $\begin{array}{l}\text { GTAATTTGTATCAAAGAGGG } \\
\text { CAATATCAATAGAAGAATTAGC }\end{array}$ & 320 & Warrit et al. 2006 \\
\hline $\mathrm{COI}$ & $\begin{array}{l}10 \mathrm{KbCOIF} 1 \\
6,5 \mathrm{KbCOIR}\end{array}$ & $\begin{array}{l}\text { CTTGTAATCATAAGGATATTGGAAC } \\
\text { AATACCAGTGGGAACCGC }\end{array}$ & 929 & Navajas et al. 2010 \\
\hline ATP6-COIII & $\begin{array}{l}16 \mathrm{KbATP} 6 \mathrm{~F} \\
16 \mathrm{kBCOIIIR}\end{array}$ & $\begin{array}{l}\text { GACATATATCAGTAACAATGAG } \\
\text { GACTCCAAGTAATAGTAAAACC }\end{array}$ & 818 & \\
\hline Cyt B & $\begin{array}{l}\text { 10KbCytbF-1 } \\
10 \mathrm{KbCytbPRIM}\end{array}$ & $\begin{array}{l}\text { GCAGCTTTAGTGGATTTACCTAC } \\
\text { CTACAGGACACGATCCCAAG }\end{array}$ & 985 & \\
\hline COII-ATP6 & $\begin{array}{l}\text { 6,5KBCOII } \\
6,5 \mathrm{KbATP} 6\end{array}$ & $\begin{array}{l}\text { GATTATTAGTTAGATCAGCAGACG } \\
\text { GTGTAAATACATAAGGTAATAACCC }\end{array}$ & 775 & \\
\hline
\end{tabular}

$58 \mathrm{~mA}$ for $3 \mathrm{~h}$. The products contained in the gel were visualized using the Silver Stain Kit (Kucharczyk; Warsaw, Poland).

Set 2: The PCR matrices $(20 \mu \mathrm{l})$ were purified with ExoSap-Exonulease I and Shrimp Alkaline Phosphatase Kits. The PCR products were directly sequenced using a BigDye Terminator Cycle Sequencing Mix v3.1 in an ABI3730xl automated DNA sequencer (Life Technologies; Warsaw, Poland).

\section{Global DNA methylation levels}

The global DNA methylation analyses were performed using an Imprint Methylated DNA Quantification Kit MDQ1 (Sigma, USA) based on the ELISA principle. We used the 96-well plate format. DNA concentration was diluted to $150 \mathrm{ng} / \mu \mathrm{l}$ in the binding solution. DNA binding was achieved by incubating $30 \mu \mathrm{l}$ diluted DNA at $37^{\circ} \mathrm{C}$ for $1 \mathrm{~h}$. One hundred fifty microliters of block solution were added, and the samples were incubated at $37^{\circ} \mathrm{C}$ for $30 \mathrm{~min}$. Next, the DNA and block solutions were removed from all the wells which were washed three times with $150 \mu$ of $1 \times$ wash buffers. Fifty microliters of diluted capture antibody were placed in each well and incubated at room temperature for $1 \mathrm{~h}$. After removing the capture antibody and washing four times with the wash buffer, each well was filled with $50 \mu$ l of diluted detection antibody. The plates were incubated at room temperature for $30 \mathrm{~min}$. The detection antibody was removed from the wells which were washed five times with the wash buffer. Each well was then filled with $100 \mu$ l of developing solution and incubated at room temperature for about $10 \mathrm{~min}$ for color change, and subsequently $50 \mu \mathrm{l}$ of stop solution were added. The absorbance of each sample was measured five times at $450 \mathrm{~nm}$. To calculate the percentages of methylated DNA cytosine relative to the methylated control DNA, in which $100 \%$ of cytosines are methylated, the following equation was used: $[(\mathrm{A} 450 \mathrm{~S}-\mathrm{A} 450 \mathrm{~B}) /(\mathrm{A} 450 \mathrm{MC}-\mathrm{A} 450 \mathrm{~B})] \times 100$. Methylated DNA weights (in nanograms) were also computed with the following equation: [(A450S-A450B)-intercept] / slope; where A450S is the average absorbance of the sample; A450MC is the average absorbance of the methylated control DNA; A450B is the average absorbance of the blank, and the intercept and slope are equal to 0.08208 and $2.68 \mathrm{e}-3$, respectively.

\section{Statistical analysis}

The differences in DNA concentrations, percentages of DNA 5-methylcytosine, and the methylated DNA weights between the control, tau-fluvalinate-sensitive, and tau-fluvalinateresistant Varroa mites were analyzed using one-way ANOVA and Tukey's test (SAS Institute Version 9.13., 2002-2003 license 86636). Bliss transformation $(y=\operatorname{arc} \sin$ $\left.(x / 100)^{0.5}\right)$ was used for percentages of DNA 5methylocytosine. The significance of differences in the mutation incidence between the groups was estimated using the $\chi^{2}$ test.

\section{Results}

Forty tau-fluvalinate-sensitive and 35 tau-fluvalinate-resistant mites were found among the 75 Varroa females from the first part. Bands were observed only in the case of COI $320 \mathrm{bp}$ in the PCR-SSCP electrophorograms. However, all taufluvalinate-resistant mites had four bands, whereas both the tau-fluvalinate-sensitive and control ones had only two bands (see Fig. 2). No differences were observed between the DNA nucleotide sequence in the control and tau-fluvalinatesensitive groups. Sense-changing mutations were identified at the frequency of $8 \%$ (test $\chi^{2} 12.00, P<0.002$ ) in the taufluvalinate-resistant mites in comparison with the two remaining groups $(0 \%)$. The sequencing results were consistent with the results of PCR-SSCP, since higher mutation frequencies corresponded with the presence of two additional bands in all the tau-fluvalinate-resistant mites (Fig. 2) as compared with the control and tau-fluvalinate-sensitive ones. 


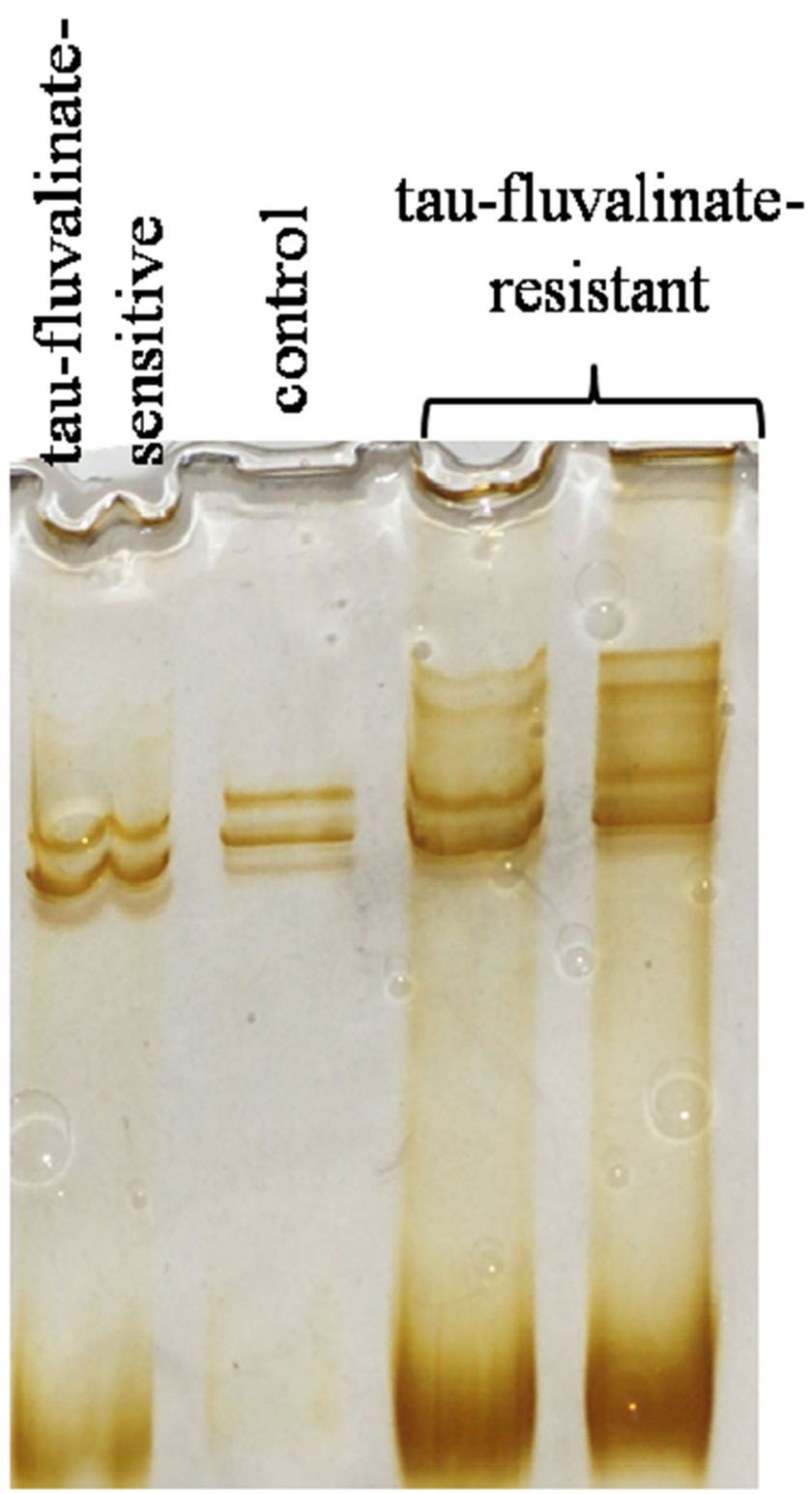

Fig. 2 An example of a PCR-SSCP electrophorogram of the Varroa mites from the control, tau-fluvalinate-sensitive, and tau-fluvalinateresistant groups

Both the DNA 5-methylcytosine percentage and the methylated DNA weight were lower in the tau-fluvalinate-resistant mites than in the control and tau-fluvalinate-sensitive ones (Table 2). Consequently, decreased DNA 5-methylcytosine percentages and methylated DNA weights corresponded with higher band numbers on the PCR-SSCP electrophorograms in the tau-fluvalinate-resistant mites.

\section{Discussion}

The development of resistance to pyrethroids, and other acaricides, usually appears between the fourth and seventh year of treatment in the Varroa mite populations (Eischen 1995; Elzen
Table 2 DNA concentrations, percentages of DNA 5-methylcytosine, and the methylated DNA weights in the Varroa mites from the control, tau-fluvalinate-sensitive, and tau-fluvalinate-resistant groups

\begin{tabular}{llll}
\hline Varroa mites & $\begin{array}{l}\text { DNA } \\
\text { concentration } \\
(\mathrm{ng} / \mu \mathrm{l})\end{array}$ & $\begin{array}{l}\text { DNA } \\
\text { methylation (\%) }\end{array}$ & $\begin{array}{l}\text { Weights of } \\
\text { methylated } \\
\text { DNA (ng) }\end{array}$ \\
& $\bar{x} \pm \mathrm{SD}$ & $\bar{x} \pm \mathrm{SE}$ & $\bar{x} \pm \mathrm{SD}$ \\
\hline Control & $5 \pm 1.9$ & $35.97^{\mathrm{a}} \pm 0.12$ & $3.05^{\mathrm{a}} \pm 0.03$ \\
Tau-fluvalinate-sensitive & $5 \pm 0.0$ & $36.17^{\mathrm{a}} \pm 0.15$ & $3.01^{\mathrm{a}} \pm 0.01$ \\
Tau-fluvalinate-resistant & $7 \pm 1.0$ & $25.01^{\mathrm{b}} \pm 0.18$ & $2.80^{\mathrm{b}} \pm 0.02$ \\
\hline
\end{tabular}

$\bar{x}$ mean value, $S D$ standard deviation, $S E$ standard error, lowercase letters the differences are statistically significant for comparison within the columns at $P \leq 0.05$

et al. 2001). Therefore, we should develop adequate methods in order to detect both the resistant mites and determine their percentages. One such method has proved to be the PCRSSCP, which helps quickly identify resistant $V$. destructor mites by detecting mutations (compare; Hayashi 1992). This method helped us detect two additional bands in our study (Fig. 2) in the SSCP-PCR electrophorograms of the drugresistant mites. The PCR-SSCP method seems promising, considering the fact that Sheen et al. (2009) and Cheng et al. (2007) obtained similar results for Mycobacterium tuberculosis, resistant to pyrazinamide, isoniazid, or rifampin.

The increased mutation rate does not explain the whole plasticity of Varroa organisms in response to toxic environment pressure. There are epigenetic modifications, which allow the genome to effectively respond to environmental signals; both harmful and useful (Kenyon 2005; Castonguay and Angers 2012). Tau-fluvalinate-resistant mites had lower percentages of global DNA methylation and lower methylated DNA weights (Table 2). The reduced levels of global DNA methylation in tau-fluvalinate-resistant parasites suggest activation of certain, previously inactive, genes.

Xia et al. (2012) suggested that unmethylated CpGs have a higher mutation rate in comparison with methylated CpGs. Flores et al. (2013) informed that mutations in targeting pathway of DNA methylation can reduce global genomic DNA methylation. This could be further investigated. Reduced levels of global DNA methylation may not only increase pyrethroid resistance by activating certain genes but also by increasing the mutation rate.

The DNA methylation pattern can be heritable (Holliday and Grigg 1993; Ledón-Rettig et al. 2012), and therefore, the epigenetic resistance to pyrethroids can be also heritable. Such factors as pyrethroids de novo alter the programming of the DNA methylation pattern during mite development (Flores et al. 2013). Therefore, we suggest a previously undescribed fourth mechanism (see "Introduction") of developing pyrethroid resistance in Varroa mites. 
The decrease in DNA methylation levels was observed in honeybees administrated such bio-stimulators as caffeine, curcumin, and coenzyme Q10 (Strachecka et al. 2014a, b, 2015a). The opposite effect was observed in the case of harmful amphotericin B (Strachecka et al. 2012) and bromofenvinphos treatments (Strachecka et al. 2015b). We observed quite the opposite effect in the Varroa mites. The harmful tau-fluvalinate treatment decreased DNA methylation levels. This implies that harmful chemotherapeutics can induce contradictory changes in DNA methylation mechanisms of honeybees and Varroa mites.

\section{Conclusions}

The PCR-SSCP method applied to gene fragments of mitochondrial COI can be used to determine the tau-fluvalinate resistance of $V$. destructor mites. We suggest that there is a previously undescribed mechanism of developing pyrethroid resistance in Varroa mites. The present article is the first report about it. This paper may set new directions for studies aimed at defining drug resistance with molecular methods.

Acknowledgments The research was partly supported by Ministry of Science and Higher Education grant no. N N311 632138.

Open Access This article is distributed under the terms of the Creative Commons Attribution 4.0 International License (http:// creativecommons.org/licenses/by/4.0/), which permits unrestricted use, distribution, and reproduction in any medium, provided you give appropriate credit to the original author(s) and the source, provide a link to the Creative Commons license, and indicate if changes were made.

\section{References}

Borsuk G, Czerska K, Olszewski K, Strachecka A, Paleolog J, Chobotow J (2012) Current state of knowledge of Varroa destructor. Med Weter 68(10):579-584

Castonguay E, Angers B (2012) The key role of epigenetics in the persistence of asexual lineages. Gen Res Int. doi:10.1155/2012/534289

Cheng X, Zhang J, Yang L, Xu X, Liu J, Yu W, Su M, Hao X (2007) A new Multi-PCR-SSCP assay for simultaneous detection of isoniazid and rifampin resistance in Mycobacterium tuberculosis. J Microbiol Methods 70:301-305. doi:10.1016/j.mimet.2007.05.002

Cornuet J, Beaumont M, Estoup A, Solignac M (2006) Inference on microsatellite mutation processes in the invasive mite, Varroa destructor, using reversible jump Markov chain Monte Carlo. Theor Popul Biol 69:129-144. doi:10.1016/j.tpb.2005.07.005

Dong K (1997) A single amino acid change in the para sodium channel protein is associated with knockdown-resistance $(\mathrm{kdr})$ to pyrethroid insecticides in German cockroach. Insect Biochem Mol Biol 27(2): 93-100. doi:10.1016/S0965-1748(96)00082-3

Eischen F (1995) Varroa resistance to fluvalinate. American Bee J 10: $815-816$

Elzen P, Baxter J, Westervalt D, Causey D, Randall C, Cuttis L, Wilson W (2001) Acaricide rotation plan for control of Varroa. American Bee J $141: 412-416$
Evans J, Lopez D (2002) Complete mitochondrial DNA sequence of the important honey bee pest, Varroa destructor (Acari: Varroidae). Exp Appl Acarol 27:69-78

Flores K, Wolschin F, Amdam G (2013) The role of methylation of DNA in environmental adaptation. Integr Comp Biol 53(2):359-372. doi: 10.1093/icb/ict019

Garedew A, Schmolz E, Lamprecht I (2004) The energy and nutritional demand of the parasitic life of the mite Varroa destructor. Apidologie 35:419-430. doi:10.1051/apido:2004032

Guerrero FD, Jamroz RC, Kammlah D, Kunz SE (1997) Toxicological and molecular characterization of pyrethroid-resistant horn flies, Haematobia irritans: identification of kdr and super-kdr point mutations. Insect Biochem Mol Biol 27(8-9):745-755. doi:10.1016/ S0965-1748(97)00057-X

Hayashi K (1992) PCR-SSCP: a method for detection of mutations. Genet Anal Tech Appl 9(3):73-79. doi:10.1101/gr.1.1.34

Hillesheim E, Ritter W, Bassand D (1996) First data on resistance mechanisms of Varroa jacobsoni (OUD.) against tau-fluvalinate. Exp Appl Acarol 20:283-296. doi:10.1007/BF00052878

Holliday R, Grigg G (1993) DNA methylation and mutation. Mutat Res Fundam Mol Mech Mutagen 285(1):61-67. doi:10.1016/00275107(93)90052-H

Johnson R, Huang Z, Berenbaum M (2010) Role of detoxification in Varroa destructor (Acari: Varroidae) tolerance of the miticide taufluvalinate. Inter J Acarol 36(1):1-6. doi:10.1080/ 01647950903468273

Kenyon C (2005) The plasticity of aging: insights from long-lived mutants. Cell 120:449-460. doi:10.1016/j.cell.2005.02.002

Koch W, Ritter W (1991) Experimental examinations concerning the problem of deformed emerging bees after infestation with Varroa jacobsoni. Zentralbl Veterinarmed B 38:337-344. doi:10.1111/j. 1439-0450.1991.tb00880.x

Kralj J, Fuchs S (2006) Parasitic Varroa destructor mites influence flight duration and homing ability of infested Apis mellifera foragers. Apidologie 37:577-587. doi:10.1051/apido:2006040

Ledón-Rettig C, Richards C, Martin L (2012) Epigenetics for behavioral ecologists. Behav Ecol. doi:10.1093/beheco/ars145

Lee S, Dunn J, Clark J, Soderlund D (1999) Molecular analysis of kdrlike resistance in a permethrin-resistant strain of Colorado potato beetle. Pestic Biochem Physiol 63(2):63-75. doi:10.1006/pest. 1999.2395

Liu Z, Tan J, Huang Z, Dong K (2006) Effect of a fluvalinate-resistanceassociated sodium channel mutation from Varroa mites on cockroach sodium channel sensitivity to fluvalinate, a pyrethroid insecticide. Insect Biochem Mol Biol 36:885-889. doi:10.1016/j.ibmb. 2006.08.006

Maggi M, Sardella N, Ruffinengo S, Eguaras M (2009) Morphotypes of Varroa destructor collected in Apis mellifera colonies from different geographic locations of Argentina. Parasitol Res 105:1629-1636. doi: 10.1007/s00436-009-1605-8

Maggi M, Ruffinengo S, Negri P, Eguaras M (2010) Resistance phenomena to amitraz from populations of the ectoparasitic mite Varroa destructor of Argentina. Parasitol Res 107:1189-1192. doi:10. 1007/s00436-010-1986-8

Maggi M, Peralta L, Ruffinengo S, Fuselli S, Eguaras M (2012) Body size variability of Varroa destructor and its role in acaricide tolerance. Parasitol Res 110:2333-2340. doi:10.1007/s00436-011-2768-7

Martin S (2004) Acaricide (pyrethrois) resistance in Varroa destructor. Bee World 85(4):67-69

Mathieu L, Faucon J (2000) Changes in the response time for Varroa jacobsoni exposed to amitraz. J Apic Res 39(3-4):155-158

Milani N (1995) The resistance of Varroa jacobsoni Oud. to pyrethroids a laboratory assay. Apidologie 26:415-429. doi:10.1051/ apido: 19950507

Miyazaki M, Ohyama K, Dunlap D, Matsumura F (1996) Cloning and sequencing of the para-type sodium channel gene from susceptible 
and kdr-resistant German cockroaches (Blattella germanica) and house fly (Musca domestica). Mol Gen Genet 252:61-68

Navajas M, Solignac M, Le Conte Y, Cros-Arteil S, Cornuet J (2002) The complete sequence of the mitochondrial genome of the honey-bee ectoparasite Varroa destructor (Acari: Mesostigmata). Mol Biol Evol 19:2313-2317

Navajas M, Anderson D, De Guzman L, Huang Z, Clement J, Zhou T, Le Conte Y (2010) New Asian types of Varroa destructor: a potential new threat for world apiculture. Apidologie 41:181-193. doi:10. 1051/apido/2009068

Park Y, Taylor M, Feyereisen R (1997) A valine421 to methionine mutation in IS6 of the hscp voltage-gated sodium channel associated with pyrethroid resistance in Heliothis virescens F. Biochem Biophys Res Commun 239(3):688-691. doi:10.1006/bbrc.1997.7511

Romero-Vera C, Otero-Colina G (2002) Effect of single and successive infestation of Varroa destructor and Acarapis woodi on the longevity of worker honey bees Apis mellifera. Am Bee J 142:54-57

Rosenkranz P, Aumeier P, Ziegelmann B (2010) Biology and control of Varroa destructor. J Invert Pathol 103:96-119. doi:10.1016/j.jip. 2009.07.016

Schneider P, Drescher W (1987) The influence of Varroa jacobsoni Oud. on weight; development on weight and hypopharyngeal glands; and longevity of Apis mellifera L. Apidologie 18:101-110. doi:10.1051/ apido:2005015

Sheen P, Mendez M, Gilman RH, Pena L, Caviedes L, Zimic MJ, Zhang Y, Moore DA, Evans CA (2009) Sputum PCR-SSCP test for sameday detection of pyrazinamide resistance in tuberculosis patients. $\mathrm{J}$ Clinical Microbiol 47(9):2937-2943. doi:10.1128/JCM.01594-08

Strachecka A, Borsuk G, Olszewski K, Paleolog J, Gagoś M, Chobotow J, Nawrocka A, Gryzińska M, Bajda M (2012) The effect of amphotericin B on the lifespan, body-surface protein concentrations, and DNA methylation levels of the honey bees (Apis mellifera). J Apic Sci 56:107-113

Strachecka A, Borsuk G, Olszewski K, Paleolog J, Lipiński Z (2013) Proteolysis on the body surface of pyrethroid-sensitive and resistant. Acta Parasitol 58(1):64-69

Strachecka A, Krauze M, Olszewski K, Borsuk G, Paleolog J, Merska M, Chobotow J, Bajda M, Grzywnowicz K (2014a) Unexpectedly strong effect of caffeine on the vitality of western honeybees (Apis mellifera). Biochem (Moscow) 79(11):1192-1201. doi:10.1134/ S0006297914110066
Strachecka A, Olszewski K, Paleolog J, Borsuk G, Bajda M (2014b) Coenzyme Q10 treatments influence the lifespan and key biochemical resistance systems in the honeybee, Apis mellifera. Arch Insect Biochem Physiol 86(3):165-179. doi:10.1002/arch.21159

Strachecka A, Olszewski K, Paleolog J (2015a) Curcumin improves the health state of Apis mellifera workers to a surprisingly large extent. J Apic Sci 59(1):129-141. doi:10.1515/JAS-2015-0014

Strachecka A, Olszewski K, Paleolog J (2015b) Varroa treatment with bromfenvinphos suppresses biochemical parameters of honeybee resistance. Entomol Exp Appl, in press.

Van Leeuwen T, Vanholme B, Van Pottelberge S, Van Nieuwenhuyse P, Nauen R, Tirry L, Denholm I (2008) Mitochondrial heteroplasmy and the evolution of insecticide resistance: non-Mendelian inheritance in action. Proc Natl Acad Sci 105(16):5980-5. doi:10.1073/ pnas.0802224105

Wang R, Liu Z, Dong K, Elzen P, Pettis J, Huang Z (2002) Association of novel mutations in a sodium channel gene with fluvalinate resistance in the mite, Varroa destructor. J Apic Res 40(1-2):17-25

Wang R, Huang Z, Dong K (2003) Molecular characterization of an arachnid sodium channel gene from the Varroa mite (Varroa destructor). Insect Biochem Mol Biol 33(7):733-739. doi:10. 1016/S0965-1748(03)00068-7

Warrit N, Smith D, Lekprayoon C (2006) Genetics subpopulations of Varroa mites and their Apis cerana hosts in Thailand. Apidologie 37(1):19-30

Watkins M (1997) Resistance and its relevance to beekeeping. Bee World 78(1):15-22

Williamson M, Martinez-Torres D, Hick C, Devonshire A (1996) Identification of mutations in the housefly para-type sodium channel gene associated with knockdown resistance (kdr) to pyrethroid insecticides. Mol Gen Genet 252(1-2):51-60

Xia J, Han L, Zhao Z (2012) Investigating the relationship of DNA methylation with mutation rate and allele frequency in the human genome. BMC Genomics 13(8):S7. doi:10.1186/1471-2164-13-S8-S7

Yukioka H, Inagaki S, Tanaka R, Katoh K, Miki N (1998) Transcriptional activation of the alternative oxidase gene of the fungus Magnophorthe grisea by a respiratory inhibiting fungicide and hydrogen peroxide. Biochim Biophys Acta 1442(2-3):161-169. doi: 10.1016/S0167-4781(98)00159-6 